American Journal of Applied Sciences 6 (8): 1604-1612, 2009

ISSN 1546-9239

(C) 2009 Science Publications

\title{
A Note on the Improvement of Evaluation System in Wholesale Markets of Agricultural and Fishery Products
}

\author{
${ }^{1}$ Yoon-Doo Kim and ${ }^{2}$ Seok Yoon \\ ${ }^{1}$ Department of Agricultural Economics, Konkuk University, \\ 322 Danwol-Dong, Chungju-Si, Chungcheonbuk-Do, 380-701, Korea \\ ${ }^{2}$ Korea National Assembly, 1 Yoido Dong, Youngdeungpo-Ku, Seoul, 150-703, Korea
}

\begin{abstract}
Problem statement: He transaction of public wholesale markets accounts for the highest rate in the distribution of agricultural and fishery products. Though the physical distribution system has improved through the revolution in distribution of 32 nationwide wholesale markets, the evaluation system in wholesale markets has not been established properly. With a rapid change of distribution environment surrounding wholesale markets such as change of consumers spending structure and stiff competition resulting from diversification of distributional channels, there needs to be an urgent improvement of evaluation system of agricultural wholesale markets. The purpose of this study is to identify the problems of evaluation system in wholesale markets, to examine the operating performance of existing evaluation system and to suggest the improvement of the system. Approach: In this context, the study reviews the whole area of evaluation system in wholesale markets and suggests the following policies for improving the system: Reclassification of evaluation objects, change of evaluation frequency and method, revision of evaluation index, effective measure of evaluation result and adjustment of weight for evaluation index. Result: The evaluation result of wholesale market should be announced earlier than present to solve the above problem. Through the early announcement, it is possible to reflect the effort for improving poor management. Conclusion: This study reviewed the evaluation system in wholesale markets and suggested the methods for improving the system such as reclassification of evaluation objects, change of evaluation frequency and evaluation method, revision of evaluation index, effective measure of evaluation result and adjustment of weight for evaluation index.
\end{abstract}

Key words: Agricultural wholesale market, evaluation system, market-wholesaler

\section{INTRODUCTION}

The transaction in public wholesale markets (hereinafter referred to as wholesale markets) accounts for the largest portion in the distribution of agricultural and fishery products. And the wholesale markets plays a key role in the distribution of agricultural and fishery products as follows: Commercial function, adjustment of demand and supply, Leading index of market activity, improvement of physical distribution, price discovery and creation of distribution information.

Especially, the markets function as a leading clue for improving distribution of agricultural and fishery products such as establishment of fair trade and grading of wholesale markets through enhancement of fair and transparent transaction, improvement of physical distribution system through standardization of productpacking and strengthening of quality control through safety test. In the above, there is no doubt that the evaluation system has made a great contribution to improvement of wholesale markets.
This study uses the basic plan on improvement in distribution structure of agricultural and fishery products for examining evaluation system in wholesale markets ${ }^{[1]}$. This evaluation system has contributed to the establishment of fair trade, growth of wholesale markets and development of evaluation policy.

However, with a rapid change of distribution environment surrounding wholesale markets such as change of consumers spending structure and stiff competition resulting from diversification of distributional channels, there needs to be an urgent improvement of evaluation system of agricultural wholesale markets ${ }^{[2]}$.

Therefore, the study identifies the problems of evaluation system in wholesale markets and examines the operating performance of existing evaluation system. Also, it reviews the whole area of evaluation system in wholesale markets and suggests the future policies for improving the system.

Corresponding Author: Yoon-Doo Kim, Department of Agricultural Economics, Konkuk University, 322 Danwol-Dong, Chungju-Si, Chungcheonbuk-Do, 380-701, Korea 
Status of evaluation system in wholesale markets: The evaluation system in wholesale markets has been conducted 14 times from 1992 until now $^{[1]}$. The results were reflected on new policies to improve the operation of wholesale markets, which improved the distribution of agricultural and fishery products and strengthened the competitiveness of wholesale markets ${ }^{[3]}$.

Objects of evaluation: The objects of evaluation are classified into 3 kinds: Founders, wholesale market corporations and joint markets and wholesalers. The founders, who are important managing subjects of wholesale markets, are local government heads of the region where the wholesale markets is established. They are composed of 3 public corporations and 28 management offices (the total is 31 places).
The 3 public corporations include Garak wholesale markets, Gangseo wholesale markets and Guri wholesale markets. And the management offices are the business units where public officials are sent by the founders to manage the wholesale markets. Also, 48 wholesale market corporations and 33 agricultural cooperative's joint markets are evaluated in this study (The total is 81 places).

Evaluation index and evaluation method: The evaluation index, which is the evaluation criteria, differs depending on the evaluation objects. First, as shown in Table 1, the index of founders consists of 3 part and 10 indexes such as effort for performing priority policy (41), effort for rearing and guiding corporations and intermediary wholesalers (20) and effort for effectively managing and operating market (39).

Table 1: Evaluation index by evaluation objects

\begin{tabular}{|c|c|c|}
\hline Division & Evaluation part (100) & Evaluation index (weight) \\
\hline \multirow[t]{12}{*}{ Founders } & \multirow{4}{*}{$\begin{array}{l}\text { Effort for performing } \\
\text { priority policy (41) }\end{array}$} & Effort for promoting electronic auction (12)-rate of electronic auction \\
\hline & & $\begin{array}{l}\text { Effort for improving physical distribution system (17)-effort for improvement of loading and unloading } \\
\text { products, carrying rate of standardized shipments }\end{array}$ \\
\hline & & Effort for enhancing quality control (8)-grade inspection system, shipper registration system \\
\hline & & $\begin{array}{l}\text { Managing results of environment-friendly agricultural products (4)-Effort for managing and promoting } \\
\text { transaction of environment-friendly agricultural products }\end{array}$ \\
\hline & \multirow{3}{*}{$\begin{array}{l}\text { Effort for guiding } \\
\text { corporations and } \\
\text { intermediary } \\
\text { wholesalers }(20)\end{array}$} & Effort for guiding and managing wholesale market corporations (10)-results of self-evaluation \\
\hline & & by corporations, guiding of financial soundness \\
\hline & & $\begin{array}{l}\text { Effort for guiding and managing intermediary wholesalers (10)-conducting evaluation of intermediary } \\
\text { wholesalers, transaction scale of intermediary wholesalers }\end{array}$ \\
\hline & \multirow{5}{*}{$\begin{array}{l}\text { Effort for } \\
\text { effectively manage } \\
\text { and operate } \\
\text { market (39) }\end{array}$} & Effort for managing and rearing transaction system (8)-effort for promoting management plan such as \\
\hline & & listed transaction and unlisted transaction \\
\hline & & Effort for enhancing customer satisfaction (13)-customer satisfaction for shippers \\
\hline & & Enhancement of feedback for evaluation result (10)-measures of evaluation result \\
\hline & & Effort for activating transaction (8)-increasing rate to average value during the last three years \\
\hline \multirow{12}{*}{$\begin{array}{l}\text { Wholesale } \\
\text { market } \\
\text { corporations } \\
\text { and joint } \\
\text { markets }\end{array}$} & \multirow{5}{*}{$\begin{array}{l}\text { Effort for } \\
\text { performing } \\
\text { priority } \\
\text { policy }(40)\end{array}$} & Effort for promoting electronic auction (9)-rate of electronic auction, effort for providing auction information \\
\hline & & $\begin{array}{l}\text { Effort for improving physical distribution system (16)-effort for improving loading and unloading of } \\
\text { products, carrying rate of standardized shipments }\end{array}$ \\
\hline & & $\begin{array}{l}\text { Effort for enhancing quality control (6)-promoting results of grade inspection system and shipper } \\
\text { registration system }\end{array}$ \\
\hline & & $\begin{array}{l}\text { Managing results of environment-friendly agricultural products (4)-effort for preferentially } \\
\text { managing environment-friendly agricultural products }\end{array}$ \\
\hline & & Effort for establishing transaction order by founders (5)-details for administrative measure of founders \\
\hline & \multirow{4}{*}{$\begin{array}{l}\text { Effort for gathering } \\
\text { and dispersing } \\
\text { products }(36)\end{array}$} & Effort for strengthening gathering activity of products (11)-transaction amount per capita of staff \\
\hline & & Effort for strengthening dispersing support of products (5)-support results of intermediary wholesalers \\
\hline & & Effort for giving preferential treatment to shippers (10)-results for providing service to shippers \\
\hline & & Effort for enhancing customer satisfaction (10)-customer satisfaction for shippers \\
\hline & \multirow{3}{*}{$\begin{array}{l}\text { Effort for managing } \\
\text { market (24) }\end{array}$} & Enhancement of feedback for evaluation result (5)-effort for improving poor evaluation results \\
\hline & & Results for educating staffs (4)-participating rate of distribution education \\
\hline & & Effort for securing financial soundness (15)-debt ratio, ordinary income rate of the sales \\
\hline \multirow[t]{9}{*}{ Wholesalers } & \multirow{4}{*}{$\begin{array}{l}\text { Effort for } \\
\text { performing priority } \\
\text { policy }(31)\end{array}$} & $\begin{array}{l}\text { Effort for enhancing transaction transparency (12)-whether the report of standard invoice and } \\
\text { standard account statement is left out }\end{array}$ \\
\hline & & Effort for expanding safety of payment (12)-rapid payment for transaction with shippers \\
\hline & & $\begin{array}{l}\text { Effort for improving physical distribution system (2)-carrying rate of standardized shipments using } \\
\text { palletized secure packaging }\end{array}$ \\
\hline & & $\begin{array}{l}\text { Results of self-evaluation and administrative measure (5)-details for self-evaluation results and } \\
\text { administrative measure of founders }\end{array}$ \\
\hline & Effort for & Effort for improving transaction results (25)-transaction amount per capita of staff \\
\hline & activating & Effort for giving preferential treatment to shippers (10)-results for providing service to shippers \\
\hline & transaction (39) & Effort for enhancing customer satisfaction (4)-customer satisfaction for shippers and consumers \\
\hline & Effort for effectively & Effort for enhancing financial soundness (28)-debt ratio, ordinary income rate of the sales \\
\hline & operating market (30) & Results for educating staffs (2)-participating rate of distribution education \\
\hline
\end{tabular}

Source: Details of evaluation in wholesale markets of agricultural and fishery products in 2006, Ministry of Agriculture and Forestry and Korea Agro-Fisheries Trade Corporation, January 2006 
Second, the evaluation index of wholesale market corporations and joint markets is composed of 3 part and 12 indexes such as effort for performing priority policy (40), effort for gathering and dispersing products (36), effort for managing market (24).

Third, the evaluation index of wholesalers is composed of 3 part and 9 indexes such as effort for performing priority policy (31), effort for activating transaction (39), effort for effectively operate market (30).

Also, the weight of evaluation index has been adjusted according to policy direction of Korean government and environmental change of wholesale markets every year ${ }^{[4]}$.

The evaluation method is classified into three kinds according to the characteristic of each evaluation index. First, in case of quantitative index, its actual value calculated by formula is evaluated. Second, qualitative index which can not be measured is evaluated by five grading (A, B, C, D and E). Third, other indexes except the quantitative and qualitative index are evaluated by adding point system after giving consideration to additional factors such as best practice and measures of evaluation result ${ }^{[5,6]}$.

Measures of evaluation result: The measures of evaluation result vary in accordance with the evaluation objects. For example, in case of wholesale market corporations and wholesalers, the support of government is increased for an excellently managed organization and it is decreased for a poorly managed organization.

First, if the performance of founders is excellent, the following support is provided ${ }^{[7]}$ : Giving a prize to people or organizations, preferential support of policy fund for facility renovation and providing opportunities of studying abroad.

On the other hand, if their performance is poor, the following measure is taken: Warning for work improvement, submitting of improvement implementation plan and checking of performance ${ }^{[8]}$.

Second, in connection with wholesale market corporations (joint markets), if their performance is superior to the others, the shipping promotion fund is provided to them at an increasing rate of $20-30 \%$ with a fall in the rate of interest. Also they receive a benefit such as additional assignment of facility use area and reduction of a rental fee of market.

If they are selected as an excellent corporation for two consecutive years, the organization is exempt from next year's evaluation. But if their performance is poor, the following measure is taken: $50 \%$ reduction of the shipping promotion fund, submitting of improvement implementation plan, checking of performance, guiding of operation improvement and enforcing of three-strike out system and advance warning system ${ }^{[9]}$.

Lastly, the measures of wholesalers are identical with those of wholesale market corporations.

Operating performance and problem of evaluation system in wholesale markets:

Operating performance of evaluation system in wholesale markets: A survey was conducted to examine the operating performance of evaluation system. The complete survey was conducted among evaluation objects such as founders, wholesale market corporations and joint markets and wholesalers. The response rate of founders, wholesale market corporations and joint markets and wholesalers were $74.2 \%$ ( 23 places of 31 places), $77.8 \%$ (63 places of 81 places) and $92.3 \%$ (48 places of 52 places) respectively.

And, the following items were examined by mail survey with structured questionnaire from November 929, 2006 (20 days): Adequacy and reasonableness by evaluation section; adequacy by evaluation index; optimal weight by evaluation index; contribution of evaluation system in wholesale markets.

If comparing the survey results by evaluation objects in Table 2, the item which showed the highest contribution was as followed: Providing of real-time auction information (54.7\%) and introduction and establishment of electronic auction (53.3\%).

On the contrary, the item which showed the lowest contribution was as followed: improvement of transaction in environment-friendly agricultural products $(13.3 \%)$ and improvement of physical distribution $(17.9 \%)$.

The founders answered that the item which showed the highest contribution was "introduction and establishment of electronic auction" (47.8\%) and "enhancement of quality control" (47.8\%). And wholesale market corporations and joint markets said that the item which showed the highest contribution was "introduction and establishment of electronic auction" (58.7\%) and the item which indicated the second highest contribution was "providing of real-time auction information" (57.1\%).

Also, wholesalers positively responded that the evaluation system contributed to "establishment of fair trade and development of wholesale markets" (67.4\%).

Establishment of fair trade and development of wholesale markets: The purpose of evaluation system in wholesale markets conducted from 1992 is to improve operation of wholesale markets, to establish fair trade and to look for ways to develop wholesale markets. In this context, the study examined how much the evaluation system contributes to achievement of this purpose. 
Am. J. of Applied Sci., 6 (8): 1604-1612, 2009

Table 2: Contribution of the evaluation system (Unit: \%)

\begin{tabular}{|c|c|c|c|c|c|c|c|c|c|c|}
\hline \multirow[t]{2}{*}{ Division } & \multicolumn{3}{|c|}{ Founders } & \multicolumn{3}{|c|}{$\begin{array}{l}\text { Wholesale market } \\
\text { corporations and joint markets }\end{array}$} & \multicolumn{3}{|c|}{ Wholesaler } & \multirow[b]{2}{*}{$\begin{array}{l}\text { Average } \\
\text { contribution }\end{array}$} \\
\hline & High & $\begin{array}{l}\text { Very } \\
\text { high }\end{array}$ & Contribution & High & $\begin{array}{l}\text { Very } \\
\text { high }\end{array}$ & Contribution & High & $\begin{array}{l}\text { Very } \\
\text { high }\end{array}$ & Contribution & \\
\hline Total & $\begin{array}{c}25.7 \\
(33.6)\end{array}$ & $\begin{array}{c}4.7 \\
(4.0)\end{array}$ & $\begin{array}{c}30.4 \\
(37.5)\end{array}$ & $\begin{array}{c}31.1 \\
(34.8)\end{array}$ & $\begin{array}{c}3.5 \\
(4.8)\end{array}$ & $\begin{array}{c}41.0 \\
(39.6)\end{array}$ & $\begin{array}{c}27.4 \\
(35.1)\end{array}$ & $\begin{array}{c}4.8 \\
(11.7)\end{array}$ & $\begin{array}{c}32.2 \\
(46.8)\end{array}$ & $\begin{array}{c}34.5 \\
(41.3)\end{array}$ \\
\hline $\begin{array}{l}\text { Establishment of fair trade and } \\
\text { development of wholesale markets }\end{array}$ & $\begin{array}{c}26.1 \\
(30.4)\end{array}$ & $\begin{array}{c}4.3 \\
(4.3)\end{array}$ & $\begin{array}{c}30.4 \\
(34.7)\end{array}$ & $\begin{array}{c}27.0 \\
(31.7)\end{array}$ & $\begin{array}{c}3.2 \\
(4.8)\end{array}$ & $\begin{array}{c}30.2 \\
(36.5)\end{array}$ & $\begin{array}{c}41.3 \\
(19.6)\end{array}$ & $\begin{array}{l}26.1 \\
(2.2)\end{array}$ & $\begin{array}{c}67.4 \\
(21.8)\end{array}$ & $\begin{array}{c}42.7 \\
(31.0)\end{array}$ \\
\hline $\begin{array}{l}\text { Introduction and establishment } \\
\text { of electronic auction }\end{array}$ & $\begin{array}{c}39.1 \\
(39.1)\end{array}$ & $\begin{array}{l}8.7 \\
(8.7)\end{array}$ & $\begin{array}{c}47.8 \\
(47.8)\end{array}$ & $\begin{array}{c}44.4 \\
(34.9)\end{array}$ & $\begin{array}{l}14.3 \\
(9.5)\end{array}$ & $\begin{array}{c}58.7 \\
(44.4)\end{array}$ & - & - & - & $\begin{array}{c}53.3 \\
(46.1)\end{array}$ \\
\hline $\begin{array}{l}\text { Providing of } \\
\text { real-time auction information }\end{array}$ & $\begin{array}{c}34.8 \\
(47.8)\end{array}$ & $\begin{array}{l}17.4 \\
(8.7)\end{array}$ & $\begin{array}{c}52.2 \\
(56.5)\end{array}$ & $\begin{array}{c}47.6 \\
(50.8)\end{array}$ & $\begin{array}{l}9.5 \\
(9.5)\end{array}$ & $\begin{array}{c}57.1 \\
(60.3)\end{array}$ & - & - & - & $\begin{array}{c}54.7 \\
(58.4)\end{array}$ \\
\hline $\begin{array}{l}\text { Improvement of physical } \\
\text { distribution system }\end{array}$ & $\begin{array}{l}13.0 \\
(21.7) \\
(34.7)\end{array}$ & $\begin{array}{l}0.0 \\
(4.3)\end{array}$ & $\begin{array}{l}13.0 \\
(26.0)\end{array}$ & $\begin{array}{c}19.0 \\
(30.2)\end{array}$ & $\begin{array}{c}0.0 \\
(0.0)\end{array}$ & $\begin{array}{l}19.0 \\
(30.2)\end{array}$ & $\begin{array}{c}19.6 \\
(39.2)\end{array}$ & $\begin{array}{c}2.2 \\
(8.7)\end{array}$ & $\begin{array}{c}21.8 \\
(47.9)\end{array}$ & 17.9 \\
\hline $\begin{array}{l}\text { Enhancement of quality control of } \\
\text { agricultural and fishery products }\end{array}$ & $\begin{array}{c}43.5 \\
(43.5)\end{array}$ & $\begin{array}{c}4.3 \\
(4.3)\end{array}$ & $\begin{array}{c}47.8 \\
(47.8)\end{array}$ & $\begin{array}{c}31.7 \\
(33.3)\end{array}$ & $\begin{array}{c}0.0 \\
(4.8)\end{array}$ & $\begin{array}{c}31.7 \\
(38.1)\end{array}$ & $\begin{array}{c}31.3 \\
(38.3)\end{array}$ & $\begin{array}{c}0.0 \\
(14.9)\end{array}$ & $\begin{array}{c}31.3 \\
(53.2)\end{array}$ & $\begin{array}{c}36.9 \\
(46.3)\end{array}$ \\
\hline Improvement of transaction result & $\begin{array}{l}13.0 \\
(21.7)\end{array}$ & $\begin{array}{l}0.0 \\
(0.0)\end{array}$ & $\begin{array}{l}13.0 \\
(21.7)\end{array}$ & $\begin{array}{c}23.8 \\
(27.0)\end{array}$ & $\begin{array}{c}3.2 \\
(3.2)\end{array}$ & $\begin{array}{c}27.0 \\
(30.2)\end{array}$ & $\begin{array}{c}27.7 \\
(34.1)\end{array}$ & $\begin{array}{c}0.0 \\
(12.8)\end{array}$ & $\begin{array}{c}27.7 \\
(46.9)\end{array}$ & $\begin{array}{c}22.6 \\
(32.9)\end{array}$ \\
\hline $\begin{array}{l}\text { Improvement of transaction result } \\
\text { of environment-friendly } \\
\text { agricultural products }\end{array}$ & $\begin{array}{c}4.3 \\
(30.4)\end{array}$ & $\begin{array}{l}0.0 \\
(0.0)\end{array}$ & $\begin{array}{c}4.3 \\
(30.4)\end{array}$ & $\begin{array}{c}22.2 \\
(36.5)\end{array}$ & $\begin{array}{l}0.0 \\
(3.2)\end{array}$ & $\begin{array}{c}22.2 \\
(39.7)\end{array}$ & - & - & - & $\begin{array}{c}13.3 \\
(35.1)\end{array}$ \\
\hline Strengthening of gathering & $\begin{array}{c}21.7 \\
(26.1)\end{array}$ & $\begin{array}{c}0.0 \\
(0.0)\end{array}$ & $\begin{array}{c}21.7 \\
(26.1)\end{array}$ & $\begin{array}{c}22.2 \\
(27.0)\end{array}$ & $\begin{array}{c}1.6 \\
(3.2)\end{array}$ & $\begin{array}{c}23.8 \\
(30.2)\end{array}$ & $\begin{array}{c}18.8 \\
(24.0)\end{array}$ & $\begin{array}{c}6.3 \\
(17.4)\end{array}$ & $\begin{array}{c}25.1 \\
(41.4)\end{array}$ & $\begin{array}{c}23.5 \\
(32.6)\end{array}$ \\
\hline $\begin{array}{l}\text { and dispersing products } \\
\text { Securing of financial }\end{array}$ & & & & & & & & & & \\
\hline $\begin{array}{l}\text { Securing of financial } \\
\text { soundness }\end{array}$ & $\begin{array}{c}30.4 \\
(30.4)\end{array}$ & $\begin{array}{l}8.7 \\
(8.7)\end{array}$ & $\begin{array}{c}39.1 \\
(39.1)\end{array}$ & $\begin{array}{c}25.4 \\
(31.7)\end{array}$ & $\begin{array}{l}6.3 \\
(7.9)\end{array}$ & $\begin{array}{c}31.7 \\
(39.6)\end{array}$ & $\begin{array}{c}37.5 \\
(36.2)\end{array}$ & $\begin{array}{c}2.1 \\
(12.8)\end{array}$ & $\begin{array}{c}39.6 \\
(49.0)\end{array}$ & $\begin{array}{c}36.8 \\
(42.6)\end{array}$ \\
\hline Enhancement of & $\begin{array}{c}26.1 \\
(47.8)\end{array}$ & $\begin{array}{c}8.7 \\
(4.3)\end{array}$ & $\begin{array}{c}34.8 \\
(52.1)\end{array}$ & $\begin{array}{c}46.0 \\
(46.0)\end{array}$ & $\begin{array}{c}3.2 \\
(4.8)\end{array}$ & $\begin{array}{c}49.2 \\
(50.8)\end{array}$ & $\begin{array}{c}18.8 \\
(52.1)\end{array}$ & $\begin{array}{c}4.2 \\
(6.3)\end{array}$ & $\begin{array}{c}23.0 \\
(58.4)\end{array}$ & $\begin{array}{c}35.7 \\
(53.8)\end{array}$ \\
\hline $\begin{array}{l}\text { customer satisfaction } \\
\text { Enhancement of }\end{array}$ & $\begin{array}{c}30.4 \\
(30.4)\end{array}$ & $\begin{array}{c}0.0 \\
(0.0)\end{array}$ & $\begin{array}{c}30.4 \\
(30.4)\end{array}$ & - & - & - & - & - & - & $\begin{array}{c}30.4 \\
(30.4)\end{array}$ \\
\hline management specialty & & & & & & & & & & \\
\hline Improvement of facility & - & - & - & $\begin{array}{c}25.4 \\
(30.2)\end{array}$ & $\begin{array}{c}0.0 \\
(1.6)\end{array}$ & $\begin{array}{c}25.4 \\
(31.8)\end{array}$ & $\begin{array}{c}23.4 \\
(36.2)\end{array}$ & $\begin{array}{c}2.2 \\
(14.9)\end{array}$ & $\begin{array}{c}25.6 \\
(51.1)\end{array}$ & $\begin{array}{c}25.5 \\
(41.5)\end{array}$ \\
\hline $\begin{array}{l}\text { and environment } \\
\text { Strengthening of }\end{array}$ & - & - & - & $\begin{array}{c}36.5 \\
(38.1)\end{array}$ & $\begin{array}{c}1.6 \\
(4.8)\end{array}$ & $\begin{array}{c}38.1 \\
(42.9)\end{array}$ & $\begin{array}{c}23.4 \\
(36.2)\end{array}$ & $\begin{array}{c}2.2 \\
(14.9)\end{array}$ & $\begin{array}{c}25.6 \\
(51.1)\end{array}$ & $\begin{array}{c}31.9 \\
(47.0)\end{array}$ \\
\hline $\begin{array}{l}\text { competitiveness } \\
\text { Use of work improvement }\end{array}$ & - & - & - & 33.3 & 3.2 & 36.5 & 32.6 & 2.2 & 34.8 & 35.7 \\
\hline
\end{tabular}

As described in Table 2, most respondents said that the evaluation system highly contributed to 'establishment of fair trade and development of wholesale markets'. For instance, the percentage of respondents who answered 'high' and 'very high' in founders, wholesale market corporations and wholesalers were $30.4,30.2$ and $67.48 \%$ respectively (the average was $42.7 \%$ ).

Introduction and establishment of electronic auction: The introduction and establishment of electronic auction is one of the important operating performance for evaluation system. Until recently, the electronic auction has been used by 79 places of 81 wholesale market corporations (joint markets) in 32 public wholesale markets. The rate of electronic auction compared with listed transaction quantity has increased every year and it reached $70.6 \%$ as of the end of 2005 .

And the electronic auction has established as a main method of auction transaction and has contributed to securing of fairness and transparency in transactions. In the survey results, most respondents thought that the evaluation system highly contributed to "Introduction and establishment of electronic auction": For instance, the contribution of founders and wholesale market corporations and joint markets were 47.8 and $58.7 \%$ respectively.

Providing of real-time auction information: About 72 wholesale market corporations (joint markets) of 32 wholesale markets provide Internet auction price in real time to meet the requirement for distribution 
information of shippers and consumers. The rate of real-time supply has continuously increased since the evaluation system was enforced.

If providing auction information, there is a positive effect such as support of decision-making, solving of distrust between shippers and consumers and prevention of dispute due to unfair trade.

In the survey results, item which showed the highest contribution was "providing of real-time auction information". For instance, the contribution of founders and wholesale market corporations and joint markets were 52.2 and $57.1 \%$ respectively (the average contribution rate is $54.7 \%$ ).

Furthermore, the future contribution rate was average $58.4 \%$, which means that the evaluation system will contribute to "providing of real-time auction information".

Securing of financial soundness: In the survey, most respondents said that the evaluation system highly contributed to securing of financial soundness. For instance, the contribution of founders, wholesale market corporations and wholesalers were 39.1, 31.7 and $39.6 \%$ respectively. And the future contribution was average $42.6 \%$ and respondents set a high value on the performance of evaluation system.

In fact, the evaluation results in 2005 shows that the evaluation system has contributed to improvement of financial soundness. In other words, if evaluation system is enforced, there is a positive effect such as reduction of the number of deficit wholesale corporations, reduction of net loss of wholesalers and impaired capital and reduction of the number of deficit wholesalers.

Enhancement of customer satisfaction: It is necessary to enhance the satisfaction of shippers and consumers who are the main customers of wholesale markets for activating wholesale markets. The survey results showed that the average contribution was $35.7 \%$ in the item "enhancement of customer satisfaction".

And in the same item, the contribution of founders, wholesale market corporations and wholesalers were $34.8, \quad 49.2$ and $23.0 \%$ respectively. Especially, wholesale market corporations responded that the evaluation system highly contributed to the "Enhancement of customer satisfaction".

Actually, according to the research on shippers and intermediary wholesalers, the customer satisfaction of public wholesale markets was 70.4 points and showed slight increases from the year before. In case of wholesalers, their research on customer satisfaction of shippers and consumers indicated that the satisfaction of consumers was higher than that of shippers.
Improvement of physical distribution system: As the evaluation system of wholesale markets has been enforced, carrying rate of standardized shipments using palletized secure packaging has increased. Also, the system for loading and unloading products has been changed from the system based on human work to advanced system using machinery.

In the survey results, most respondents did not answer that the evaluation system highly contributed to "improvement of physical distribution system". For instance, the contribution of founders, wholesale market corporations and wholesalers were 13, 19 and $21.8 \%$ respectively. That is, the rate was lower than that of other items.

Improvement of transaction result in environmentfriendly agricultural products: The transaction of environment-friendly agricultural products accounts for $1.7 \%$ (93,344 ton) of total transaction quantity of wholesale markets as of 2005: The rate is insignificant. But wholesale markets try to reduce a consignment fee of environment-friendly agricultural products and the transaction of environment-friendly agricultural products will be activated to meet the need of consumers.

In the survey results, the present contribution of evaluation system is average $13.3 \%$ and it is slight. But the future contribution of the system is $35.1 \%$ and it is 2.6 times as high as the present contribution.

Problems of evaluation system in wholesale markets: Problem of classification for evaluation objects: As 32 wholesale markets have been established and operated, the number of evaluation objects who are founders, wholesale market corporations and joint markets and wholesalers have increased rapidly. And the evaluation objects try to expand the functions of wholesale markets and consider how to cope with location requirements and operating scale of each region to gain an advantage over other distributional channels ${ }^{[10]}$.

But the market performance ${ }^{[11]}$ has been evaluated uniformly without considering the difference of regional environment and economic conditions and the policy of each wholesale markets.

Problem of evaluation method: In the present evaluation system, wholesale markets are evaluated by three kinds of methods such as actual value calculated by formula, grading and adding point system according to the characteristic of each evaluation index. But the evaluation is actually performed focusing on the submitted documents, so it can not reflect the current situation in the field of market improvement. 
And most of quantitative indexes and qualitative indexes center on the specific evaluation objects, which cause the decline in effectiveness of evaluation.

For example, the rate of qualitative indexes of founders, wholesale market corporations and wholesalers are 39,13 and $0 \%$ respectively: That is, the rate of qualitative indexes of founders is considerably higher than that of others. If there is no qualitative index such as the case of wholesalers, it is difficult to evaluate the qualitative performance including business mind and marketing ability.

Problem of evaluation index: The evaluation index, which is evaluation criteria, is composed of 3 part. And the number of index in founders, wholesale market corporations and wholesalers are 10, 12 and 9 respectively. In other words, the number of index differs depending on the role of evaluation objects.

In the survey on whether the indexes were appropriate, most respondents answered that the following indexes were not suitable for evaluating the objects: "efforts for improving physical distribution system", "managing results of environment-friendly agricultural products" and "efforts for improving transaction results".

This means that when standardized packaging is not firmly established in the production field, it is unreasonable to evaluate the evaluation objects by carrying rate of standardized shipments. And it is difficult to improve physical distribution system only by efforts of wholesale market subjects such as founders, wholesale market corporations and joint markets and wholesalers without mutual cooperation with production field.

Problem of measure for evaluation result: According to the survey on measures (preferential treatment and restraint) of evaluation result, the rate of respondents who answered "appropriate" for the measures was higher than that of respondents who answered "inappropriate". But the rate of respondents who answered "average" was much higher than that of above respondents: That is, they did not offer clear-cut response for the measures.

Therefore, the effective measure should be devised as early as possible to induce positive efforts for improving the market performance.

At present, as a preferential treatment, shipping promotion fund is differentially provided depending on the evaluation result. But substantial incentive is not provided sufficiently in addition to this differentiated support.

In connection with restraint, there is no effective penalty except the reduction of shipping promotion fund. That is, with lack of restraint, the incentive program is not properly prepared for effective market operation, business management and transaction activation. Especially, in case of restraint on founders, it has limited effectiveness in pressuring founders.

Problem of feedback of evaluation result: The index, "feedback of evaluation result" is included in the evaluation indexes of founders and wholesale market corporations. In the survey on whether the indexes were appropriate, the rate of respondents who answered "average" in founders and wholesale market corporations were 56.5 and $55.6 \%$ respectively: The majority of respondents provided the same answer. And the rate of respondents who answered "appropriate" in founders and wholesale market corporations were 30.4 and $36.5 \%$ respectively: The rate of positive answer was higher than that of negative answer.

However, some serious problems arise from the condition for performing the feedback of evaluation result. Unfortunately, any improvement of poor management can not be reflected because the evaluation result to achievement in management of this year is announced in November next year, the urgency of the situation precludes.

Problem of weight for evaluation index: The sum of weight for evaluation indexes is 100 and the weight differs depending on the evaluation objects and indexes. The weight means importance by evaluation items. The weight of founders is in the lowest 4-highest 17 range and that of wholesale market corporations and joint markets is in the lowest 4-highest 16 range.

But the weight range of wholesalers is from lowest 2 to highest 28 and the deviation of weight is 26 , which shows excessive difference in weight of indexes. The sum of weights of top 2 indexes is 53, it is more than half of whole weights and the weight gives too much importance to the specific indexes. Also, the weight of same index considerably differs in accordance with evaluation objects, which can cause unfair results of evaluation.

\section{Improvement of evaluation system in wholesale markets:}

Reclassification of evaluation objects: As shown in the evaluation system, it is not appropriate to simply classify wholesale markets into central wholesale markets and local wholesale markets because there is a large difference of scale in the central wholesale markets.

If applying operation exception to local wholesale markets pursuant to the revised Act on the Marketing and Price Stabilization of Agricultural and Marine 
Products, the central wholesale markets which are not more competitive than local wholesale markets, for example Ulsan wholesale markets, would be in a disadvantageous position.

Also, if classifying wholesale markets into existing markets and new markets (markets less than five years), which is not effective because there are only two new markets: Seoul Gangseo agricultural wholesale market established in 2004 and 2nd Gwangju wholesale market.

Therefore, it is reasonable to use the classification which two method are mixed: (1) the method which wholesale markets are classified into central wholesale markets and local wholesale markets (2) the method which wholesale markets are classified according to the difference of management scale.

\section{Improvement of evaluation method:}

Frequency of evaluation: Basically, the evaluation of wholesale markets is performed once a year. And to improve evaluation method, the evaluation items should be classified into two types in accordance with frequency of evaluation:

First, the item to be evaluated once a year and second, the item to be evaluated once every other year. Through this method, the evaluation system can cope with environmental change and its cost is reduced.

For example, the index, "enhancement of feedback for evaluation result" should be evaluated once every other year because if trying to perform the feedback, which is restricted by time. And "carrying rate of standardized shipments" should be evaluated once every other year because standardized packaging is not firmly established in the production field.

Evaluation point distribution and relative evaluation method: At present, in the evaluation point distribution, actual value is calculated by formula and the point of applicable interval is applied to the value. But the range of applicable interval is too large to discriminate the difference between points. In case of relative evaluation method, the range of grade is too wide to reflect the actual difference between evaluation objects.

Therefore, if evaluating quantitative index and qualitative index, current 5 grading should be changed to 9 grading to reflect the actual difference between evaluation objects.

In addition, various evaluation methods, rather than present simple methods, should be introduced in the evaluation of quantitative indexes. Especially, in case of wholesale market corporations and wholesalers, the rate of qualitative index is excessively reduced, so evaluation of qualitative results can not be performed properly. Therefore, it is necessary to devise the method for securing the appropriate rate between quantitative index and qualitative index.

Revision of evaluation index: The same index should be applied to every evaluation objects in order to set evaluation index properly. Especially, the index of wholesale market corporations needs to be identical with that of wholesalers.

For instance, three evaluation indexes which are included in the index of wholesale market corporations but not included in that of wholesalers have to be added in the index of wholesalers: 1) "efforts for enhancing quality control", 2) "results of managing environmentfriendly agricultural products" and 3) "enhancing of feedback for evaluation result". Through the above, the operating subjects of wholesale market can be consistently evaluated.

The plan for improving evaluation index should be made by evaluation objects to rapidly revise the index in accordance with the change of wholesale markets: for example, if electronic auction is established completely, the item of electronic auction rate should be deleted; if sales chart correction system is supplied with all wholesale markets, the operating performance item of the correction system should be deleted; if shipper registration system has been enforced since 2009 , the item of shipper registration should be deleted.

Effective measures of evaluation result: At present, shipping promotion fund and opportunities of studying abroad are differentially supported as a preferential treatment depending on the evaluation result. But there is no incentive program which is effective enough to induce positive efforts for improving the market performance. That is, it is necessary to prepare the substantial preferential treatment as follows: preferential budget allocation of facility renovation and relieving of payment guarantee condition for operating fund loan.

Also, in connection with restraint, effective penalties should be enforced for wholesale market corporations and wholesalers as follows: differentiated assignment of market use area, obligatory conducting of management consulting and compulsory education of staff. Especially, in case of founders, it is required to decrease the policy fund of government for a poorly managed organization.

Adjustment of weight for evaluation index: The appropriate weight is given to evaluation index to evaluate whether the managing subjects try to manage 
wholesale markets properly. But the weight of same index differs considerably depending on the evaluation objects.

In case of wholesalers, the deviation of weight between indexes is maximum 26. And the sum of weights of top 2 indexes is 53, it has more than half of whole weight and the weight gives too much importance to the specific indexes.

Therefore, the weight should not be centered on several indexes. And the weight has to be adjusted so that the weight of same index does not differ considerably depending on the evaluation objects. Also, the weight should be reduced according to the average achievement of evaluation index and it should be expanded to cope with rapid environmental change.

\section{MATERIALS AND METHODS}

The framework for this study is basically theoretical approach. There is nothing special methods for analysis. However, It gives analysis tactics through the questionaire. According to the result of questionaire, this study provides political implications and current system contrariety.

\section{RESULTS}

Substantial feedback of evaluation result: The weight of founders and wholesale market corporations and joint markets are 10 and 5 respectively in the index, "enhancement of feedback for evaluation result". But the urgency of the situation precludes any improvement of poor management because the evaluation result to achievement in management of this year is announced in November next year.

Therefore, the evaluation result of wholesale market should be announced earlier than present to solve the above problem. Through the early announcement, it is possible to reflect the effort for improving poor management.

If evaluation result can not be announced in advance, the index, "enhancement of feedback for evaluation result" should be applied to the evaluation objects once every other year. Also, it is necessary to consider how to evaluate the effort for improving poor management.

\section{DISCUSSION}

The results of this study should be announced earlier than present to solve the above problem. Through the early announcement, it is possible to reflect the effort for improving poor management.
Shippers and consumers, who are users of wholesale markets, hope that the evaluation system will be improved to enhance customer satisfaction. That is, they think that the item related to expansion and improvement of facilities should be newly organized and the item related to environmental improvement has to be given more weight in the evaluation system.

On the other hand, policy authorities expect to improve the evaluation system, carrying out a consistent and effective policy from mid-to long-term point of view. As a result, when the competitiveness of wholesale markets is enhanced, which will be of help to producers and consumers.

Therefore, the study identifies the problems of evaluation system in wholesale markets and examines the operating performance of existing evaluation system.

\section{CONCLUSION}

As the evaluation system in wholesale markets has been conducted 14 times from 1992 until now, the system contributed to improvement of market distribution and development of wholesale market. Especially, the fair trade was established through the following two items of evaluation system: Introduction and establishment of electronic auction and providing of real-time auction information.

In addition to the above, the system provides various achievements related to management of wholesale markets: enhancement of quality control of agricultural and fishery products; securing of financial soundness; improvement of physical distribution system; enhancement of customer satisfaction.

The distribution environment surrounding wholesale markets rapidly changes under the situation such as opening of distribution market, establishment of 32 nationwide wholesale markets, change of consumers spending structure and appearance of wholesalers who are new distribution subjects.

In this context, this study reviewed the evaluation system in wholesale markets and suggested the methods for improving the system such as reclassification of evaluation objects, change of evaluation frequency and evaluation method, revision of evaluation index, effective measure of evaluation result and adjustment of weight for evaluation index.

However, this study has limitations as follows: it analyzed the evaluation system in wholesale markets based on the opinions of evaluation objects and did not widely collect the opinions about wholesale market users and policy authorities. 
Shippers and consumers, who are users of wholesale markets, hope that the evaluation system will be improved to enhance customer satisfaction. That is, they think that the item related to expansion and improvement of facilities should be newly organized and the item related to environmental improvement has to be given more weight in the evaluation system.

On the other hand, policy authorities expect to improve the evaluation system, carrying out a consistent and effective policy from mid-to long-term point of view. As a result, when the competitiveness of wholesale markets is enhanced, which will be of help to producers and consumers.

Last but not least, the evaluation system in wholesale markets should induce positive effort of founders, wholesale market corporations and joint markets and wholesalers through the consistent evaluation and complementary measures. Also, the government should provide the policy framework which is of help to both producers and consumers.

\section{AKNOWLEDGEMENT}

This study was supported by Konkuk university research fund.

\section{REFERENCES}

1. Ministry of Agriculture and Forestry, 1991. Improvement in distribution structure of agricultural and fishery products. pp: 76-79.

2. Ministry of Agriculture and Forestry and Korea Agro-Fisheries Trade Corporation, 2004-2007. Evaluation report on wholesale markets of agricultural and fishery products. pp: 1-313.
3. Ministry of Agriculture and Forestry, 2004-2007. Statistical yearbook on wholesale markets of agricultural and fishery products. pp: 1-208.

4. Ministry of Agriculture and Forestry and Korea Agro-Fisheries Trade Corporation, 2007. Evaluation details on wholesale markets of agricultural and fishery products. pp: 1-78.

5. Korea Agro-Fisheries Trade Corporation, 2003. Management consulting manual for wholesalers. pp: 30-54.

6. Seoul agricultural and Marine Products Corporation, 2006. Report on management performance in 2005. pp: 379-623.

7. Wang, S. et al., 2006. A study on the roadmap establishment for wholesale markets, Baekseok University, pp: 1-181.

8. Lee, D., 1998. Operational status and development direction for evaluation system in wholesale markets of agricultural and fishery products. Food Distribut. Stud., 5: 39-52.

9. Jeon, T., 2001. Problem and improvement on distribution of environment-friendly agricultural products. Food Distribut. Stud., 18: 73-95.

10. Jung, K. et al., 2006. Management Analysis and Market Environment Analysis. Parkyoungsa Co., ISBN: 89-91184-00-6, pp: 37-101.

11. Korea Rural Economic Institute, 2004. Activation of management in wholesale market of agricultural and fishery products. KREI C2004-38: 1-159. 